MRS Advances (C) 2018 Materials Research Society. This is an Open Access article, distributed under the terms of the Creative Commons Attribution licence (http://creativecommons.org/licenses/by/4.0/), which permits unrestricted re-use, distribution, and reproduction in any medium, provided the original work is properly cited. DOI: 10.1557/adv.2018.231

\title{
The Need for Integrating the Back End of the Nuclear Fuel Cycle in the United States of America
}

\author{
Evaristo J. Bonano, Elena A. Kalinina, and Peter N. Swift \\ Advanced Nuclear Energy Programs, Sandia National Laboratories, Albuquerque, New Mexico, USA \\ 87185
}

ABSTRACT

Current practice for commercial spent nuclear fuel management in the United States of America (US) includes storage of spent fuel in both pools and dry storage cask systems at nuclear power plants. Most storage pools are filled to their operational capacity, and management of the approximately 2,200 metric tons of spent fuel newly discharged each year requires transferring older and cooler fuel from pools into dry storage. In the absence of a repository that can accept spent fuel for permanent disposal, projections indicate that the US will have approximately 134,000 metric tons of spent fuel in dry storage by mid-century when the last plants in the current reactor fleet are decommissioned. Current designs for storage systems rely on large dual-purpose (storage and transportation) canisters that are not optimized for disposal. Various options exist in the US for improving integration of management practices across the entire back end of the nuclear fuel cycle.

\section{INTRODUCTION}

Spent nuclear fuel and high-level radioactive wastes have been generated in the United States of America (US) since the early 1940s. By the time the first commercial power plant came into service in the US in 1957, there was a growing recognition that deep geologic disposal was the best available option for permanently isolating highly radioactive wastes [1]. Every nation that has pursued nuclear power has subsequently come to the same conclusion: deep geologic disposal is the preferred option for isolating spent nuclear fuel and high-level radioactive waste [2-4]. Six decades after the beginning of commercial nuclear power, however, no nation has an operating deep geologic disposal facility for commercial nuclear waste.

For most of the early history of commercial nuclear power in the US, including the period of rapid expansion in the late 1960s and 1970s, electric utility companies operated reactors with an expectation that spent nuclear fuel would be reprocessed to recover fissionable material for use in new reactor fuel. A modest amount (640 metric tons) of spent nuclear fuel was reprocessed between 1966 and 1972 at the privatelyoperated Western New York Nuclear Service Center near West Valley, New York, but the reprocessing facility was closed in 1972 [5], and no commercial reprocessing of spent nuclear fuel has occurred in the US since then. The federal government suspended efforts to develop additional reprocessing facilities in 1976 [6], and despite the removal 
of those restrictions in 1981 [7], no new reprocessing facilities have been constructed in the US.

Recognizing the need for a clear national policy regarding wastes from both commercial and defense-related nuclear enterprises, Congress passed the Nuclear Waste Policy Act (NWPA) in 1982 [8]. The NWPA established a federal responsibility for permanent disposal of all spent nuclear fuel and high-level radioactive waste, and required the Department of Energy (DOE) to evaluate multiple repository sites and to license and construct a disposal facility that would begin operations in 1998. This repository would be limited to a disposal inventory of 70,000 metric tons of heavy metal (MTHM), either in the form of spent fuel or an equivalent quantity of high-level radioactive waste, and, as prescribed in the 1982 Act, a second repository would be licensed and constructed three years after the first to accommodate additional wastes. Private utilities would pay a fee of $\$ 0.001 / \mathrm{kWh}$ into the Nuclear Waste Fund to pay for the federal repository, and would retain responsibility for storing and managing spent nuclear fuel until the DOE took title to the material for transport to the repository.

In 1987, Congress amended the NWPA to identify Yucca Mountain, Nevada, as the only site for further evaluation as a repository, to defer action on a second repository, and to preclude site-specific activities associated with any location other than Yucca Mountain without specific Congressional authorization. The provisions of the NWPA, as amended, remain in effect today, but little of what the law envisioned has come to pass. By the early 1990s it was apparent that the Yucca Mountain repository would not open as required in 1998, and utilities began planning to store more spent nuclear fuel on-site. Reactor pools were reconfigured to accommodate more fuel assemblies, and as pools approached capacity limits, utilities moved forward with implementing on-site dry cask storage systems. DOE submitted a license application for Yucca Mountain to the Nuclear Regulatory Commission (NRC) in 2008 [9], twenty-one years after the date envisioned in the 1982 law, but the DOE withdrew support for the project in 2010 and Congress suspended funding for the licensing process.

As of 2017, the Yucca Mountain repository licensing process remains suspended, the US government is considering no other sites for disposal, and spent nuclear fuel continues to accumulate in dry storage at commercial reactor sites. The DOE has not taken title to any commercial spent nuclear fuel, and most nuclear utilities have successfully brought suit against the US government for its failure to honor contractual requirements to begin disposal operations in 1998. The future of commercial spent nuclear fuel management in the US remains uncertain, with few options available other than continued on-site storage at power plants until such time as the NWPA is amended. The trend of the last decade for older and less profitable nuclear power plants to close seems likely to continue, leaving increasing quantities of spent nuclear fuel stored at sites where the fuel pool and handling facilities have been decommissioned. Consolidated interim storage facilities have been proposed that could accommodate some spent fuel from both decommissioned and operating sites, but these sites remain to be licensed and their viability is uncertain without modifications to the portions of the NWPA that link federal interim storage to repository licensing and operation. If Congress chooses to permanently abandon the Yucca Mountain site and pursue as-yetunidentified alternatives, the DOE's projections indicate that a repository will not be available before mid-century [10]. If Congress chooses to restart the licensing process for Yucca Mountain, extrapolation from DOE's 2009 projection of a 2020 date for first disposal operations [11] indicates that disposal operations are unlikely to begin any sooner than roughly ten years after hearings resume, assuming a favorable licensing decision from the NRC and full Congressional funding. 


\section{CURRENT STATUS OF COMMERCIAL SPENT NUCLEAR FUEL MANAGEMENT IN THE US}

As of December 2016, approximately 77,000 MTHM of commercial spent nuclear fuel were stored at 75 sites in 33 states (Figure 1). Approximately 50,000 tons are stored in pools, either at reactor sites or, in one instance, in an off-site pool at the GE Morris facility in Illinois. The remaining 27,000 tons are stored in a variety of dry cask storage systems, at active or decommissioned reactor sites (Figure 2).

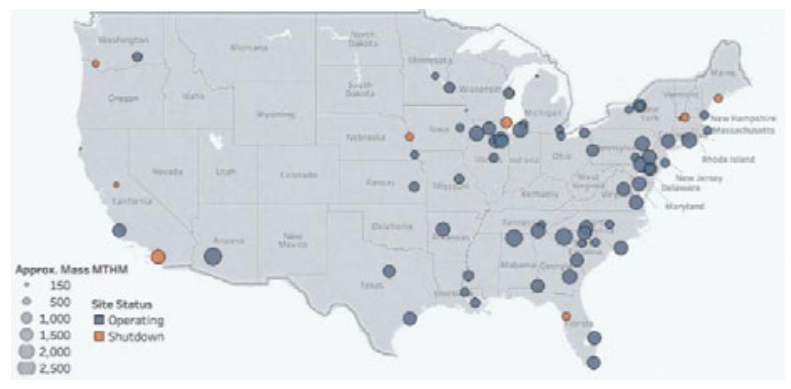

Figure 1: Location of spent nuclear fuel in the USA. Data from [12]
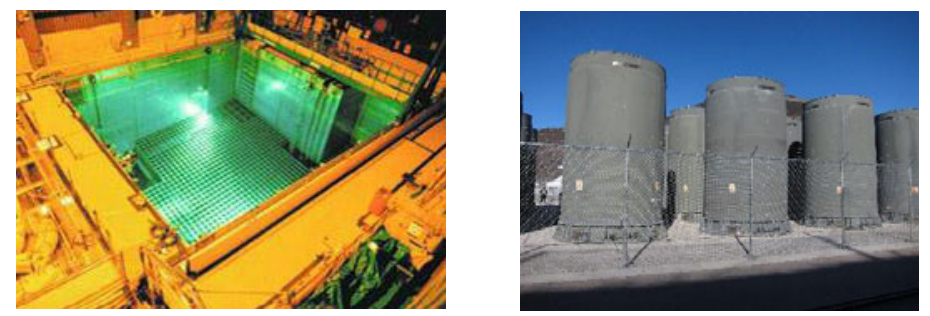

Figure 2: Spent nuclear fuel at reactor sites in pool storage left) [13] and dry storage (right) [14, right photograph by C.R. Bryan, Sandia National Laboratories].

Multiple dry storage systems are in use in the US today, including vertical cask/canister systems on concrete pads such as those illustrated in Figure 2, vertical cask/canister systems emplaced below grade, and horizontal systems with canisters emplaced in modular concrete storage units [15]. Most systems place fuel assemblies in stainless steel dual-purpose canisters (DPCs) that are certified by the NRC for both storage and transportation. Canisters are loaded in fuel pools, removed from the pools in shielded transfer casks to allow closure with welded lids, dewatering, and filling with 
helium gas before final sealing. They are then placed in concrete or concrete and steel overpacks for shielding and physical protection during storage. Transportation of DPCs requires removal of the sealed canister from the storage overpack and emplacement in a reusable transportation cask.

Individual specifications vary, but typical DPCs are approximately 2 meters in diameter and 5 meters in length, and the largest currently in use in the US accommodates up to 37 pressurized water reactor (PWR) fuel assemblies or 89 boiling-water reactor (BWR) assemblies. A loaded canister may weigh more than 50 metric tons, and transportation shielding may increase the weight to 150 metric tons. There are approximately 2,200 cask/canister storage systems deployed in the US today, with approximately 160 new canisters loaded each year.

\section{FUTURE PROJECTIONS OF SPENT NUCLEAR FUEL AND HIGH-LEVEL RADIOACTIVE WASTE IN THE US}

Figure 3 shows the estimated and projected inventory of US commercial spent nuclear fuel from 1995 through 2060. Projections are based on assumptions that 1) the nine existing nuclear power plants that have announced shutdown dates continue operating until those dates; all others receive license renewals and are decommissioned after 60 years of operation, 2) no new reactors are built, 3) no spent nuclear fuel is reprocessed, and 4) there are no options for permanent disposal and all spent nuclear fuel remains in temporary storage. Each of these assumptions is open to criticism, and details of the projection should be interpreted with caution. The overall trends shown in Figure 3 are important, however.

- Approximately 2,200 MTHM of commercial spent nuclear fuel are generated each year in the US.

- Most reactor pools in the US have been filled to capacity since approximately 2012, and pool storage of newly discharged spent nuclear fuel at most locations now requires transferring older and cooler fuel to dry storage.

- More spent nuclear fuel will be in dry storage than in pools by some time between 2025 and 2030.

- Pool storage capacity will decrease after approximately 2035 as older reactors are shut down and decommissioned, and by mid-century nearly all commercial spent nuclear fuel will be in dry storage.

- The total mass of spent nuclear fuel generated by the existing US reactor fleet by mid-century will be on the order of 134,000 MTHM, which is nearly twice the limit established by the NWPA for the proposed Yucca Mountain repository.

The assumption that none of the US inventory of commercial spent nuclear fuel will be reprocessed between now and 2060 warrants further discussion. US law and national policy do not preclude reprocessing, and it is possible that future nuclear power generation activities in the US will implement a closed fuel cycle that would change projections shown in Figure 3. However, no capacity for commercial reprocessing exists today in the US, and there is no plausible near-term path for constructing such capacity. The slope of the total inventory curve in Figure 3 is unlikely to change due to reprocessing within the next ten to twenty years. Even if reprocessing capabilities were available, there is no realistic scenario under which large amounts of existing spent nuclear fuel might be reprocessed, because the new discharges of 2,200 MTHM per year would be more than sufficient to provide initial feedstock for a new generation of reactors operating within a closed fuel cycle [16]. Reversing the trends shown in Figure 
3 and decreasing the total US inventory of commercial spent nuclear fuel in storage will require permanent disposal in a geologic repository.

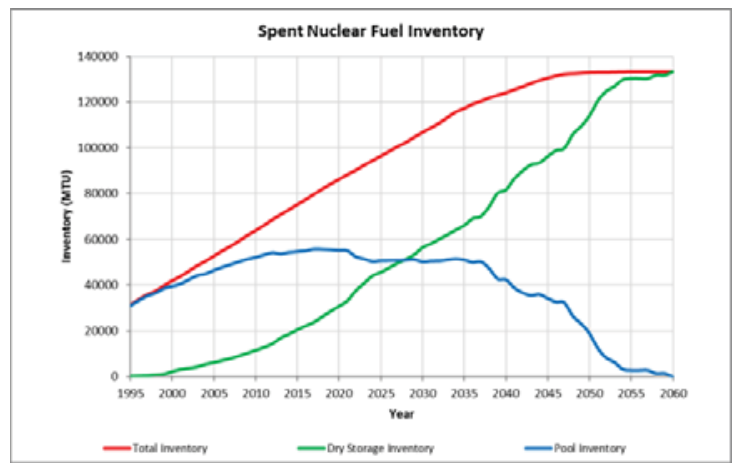

Figure 3: Projected inventory of US commercial spent nuclear fuel in storage (data from [17]). Projections assume 1) the nine existing nuclear power plants that have announced shutdown dates continue operating until those dates; all others receive license renewals and are decommissioned after 60 years of operation, 2) no new reactors are built, 3) no spent nuclear fuel is reprocessed, and 4) there are no options for permanent disposal and all spent nuclear fuel remains in temporary storage.

\section{OBSERVATIONS ON CURRENT US PRACTICE FOR THE MANAGEMENT OF COMMERCIAL SPENT NUCLEAR FUEL}

Three observations about current US practice for the management of commercial spent nuclear fuel provide a foundation for storage, transportation, and disposal planning. First, current practice is safe and secure. Second, current practice is optimized for reactor operations. Third, current practice is not optimized for transportation or disposal of spent nuclear fuel. Each of these observations is discussed in more detail in the following sections.

\section{Current practice is safe and secure}

As determined by the NRC, current storage practices for commercial spent nuclear fuel are safe and secure, and associated risks to the public are extremely small $[18,19]$. As long as storage facilities are properly maintained, institutional controls remain in place, and regulatory oversight and enforcement remains effective, public safety standards can and will be met.

There is no question, however, that extending storage operations decades longer than originally intended raises questions about fuel and canister performance and subsequent transportability over longer time periods. In addition, most available data on fuel performance in storage are from older relatively low-burnup fuel. Current trends in industry are to irradiate fuel longer in reactors, achieving higher levels of burnup that may result in different behaviour of fuels during storage, transportation, and disposal. Industry, NRC, and the DOE are conducting ongoing research and development activities to confirm storage-system performance and to identify monitoring and agingmanagement practices needed to ensure safety of future operations [20] and to assess 
changing needs for site-specific physical security as fuel ages and reactors are decommissioned. Ongoing research focuses on evaluating 1) the integrity of cladding, including high-burnup fuel, during extended storage, 2) the integrity of storage canisters during extended storage, including the potential for chloride-induced stress corrosion cracking in coastal environments, and 3) the transportability of spent nuclear fuel, including high-burnup fuel, following extended storage [21-23].

\section{Current practice is optimized for reactor operations}

Utilities that operate nuclear power plants in the US must meet all operational safety and security requirements while fulfilling obligations to public utility commissions, ratepayers, and shareholders to provide electric power at competitive costs. Activities associated with the on-site storage of spent nuclear fuel must therefore ensure full safety for site workers and the general public while causing the least disruption to the cost-effective operations of the reactor. In practice, these constraints favor loading large DPCs that require the fewest on-site handling operations. Canister sizes have increased in the past decade, with size ultimately limited by practical considerations associated with on-site handling and transportation.

\section{Current practice is not optimized for transportation and disposal}

The current practice in the US of loading large DPCs is appropriate given the financial, legal, and regulatory constraints imposed on the utilities that generate and manage spent nuclear fuel. However, the practice may not be an optimal solution for the full back end of the nuclear fuel cycle, including interim storage at operating reactor sites, subsequent transportation to either consolidated interim storage sites or repositories, and eventual permanent disposal. In part, this potential for a suboptimal spent nuclear fuel management system has its roots in the NWPA, which transfers ownership of, and management responsibility for, spent nuclear fuel from the utilities to the federal government when disposal operations begin. Long delays in the availability of a repository have also contributed to the lack of integration. When the NWPA was written, no spent nuclear fuel was in dry storage, and planning for transportation and disposal assumed handling operations would begin with bare fuel assemblies. As shown in Figure 3, when DOE submitted the Yucca Mountain License Application in 2008, the total amount of spent nuclear fuel in dry storage was still small, and the proposed concept of loading fuel assemblies into disposal-ready transportation, aging, and disposal (TAD) canisters at the reactor sites made sense. In the absence of a federal commitment to Yucca Mountain or any other disposal concept, utilities will continue to load DPCs and the disconnect between the system envisioned in the NWPA and operational reality will continue to grow.

\section{Implications of current practice for transportation.}

DPCs are large, and are both hot and heavy when fully loaded. Technical challenges associated with moving massive casks are relatively straightforward and can be addressed using available technology, but the magnitude of the enterprise should not be underestimated. Even if consolidated interim storage or disposal sites were available and ready to receive spent nuclear fuel, some (but relatively few) dry storage containers in use today are not certified for transport, and transportation routes from some storage sites are uncertain $[15,24]$. Rail cars remain to be designed and built [25], some transportation casks remain to be certified by the NRC, and in some cases DPCs may 
need to remain on-site for further decay cooling before they reach thermal and dose limits established for transportation [15].

As an example of the thermal implications of DPC loadings with respect to transportation, Figure 4 shows the range of required aging times established by the NRC in its certificates of compliance for various transport cask configurations. Aging times are specified as a function of fuel burnup, and the upper limits assume maximum loading density in the canisters. Aging times vary with the specific details of the cask/canister system (some are more efficient at heat transfer than others) and the assumptions made regarding loading schemes. The figure can reasonably be interpreted as showing that some cask/canister systems can be transported as soon as 6 or 7 years after fuel is removed from the reactor regardless of the fuel's burnup, but other systems may require decades of aging before they can be moved. Note, however, that these are upper bounds specified in the NRC's certificates of compliance for maximally-loaded canisters. In practice, site operators tend to load canisters with lower heat loads, and few if any existing canisters will approach the upper limits.

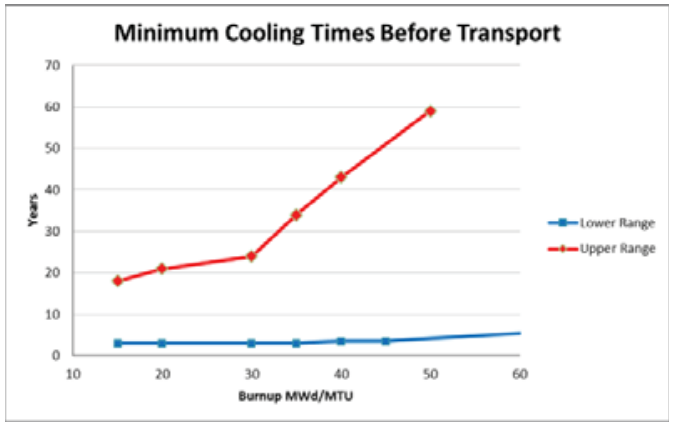

Figure 4. Minimum cooling times for multiple cask/canister systems, as reported in NRC certificates of compliance for specific designs as of 2013. Variation in times is due to the diversity of cask/canister system designs, and is dominated by DPC size and heat transfer capabilities. Modified from [26].

\section{Implications of current practice for disposal}

DPCs are substantially larger and more massive than waste packages considered in any current disposal concept design other than the proposed Yucca Mountain repository, and they are incompatible with disposal concepts being considered in nations other than the US. For example, Swedish, Finnish, and French concepts [2729] call for disposal of spent fuel in waste packages containing four PWR fuel assemblies (or equivalent amounts of other fuel types), rather than the 32 or more PWR assemblies typical of US DPCs. Necessary modifications to existing repository design concepts other than Yucca Mountain to accommodate the size and mass of DPCs could be extensive, including changes in hoist or ramp design, emplacement drift dimensions, and emplacement transporter technology, but they appear to be achievable using current engineering technology [30]. Modifications to disposal concepts similar to Yucca Mountain could be more straightforward, given the larger size of TAD canister specified for the repository (21 PWR assemblies per waste package) and the use of rails and an inclined ramp for waste emplacement. 
The greater thermal power of large waste packages may pose a more significant challenge to most existing disposal concept designs because the difficulty of transferring decay heat away from packages after emplacement may cause temperatures to rise above intended limits $[30,31]$. Figure 5 shows representative estimates of aging times required before repository closure for a hypothetical waste package containing 32 PWR assemblies to meet temperature constraints for representative repository designs in sedimentary or hard rocks (e.g., clay/shale or granite) with a clay buffer, hard rocks without a clay buffer, and salt. Decay curves indicate the thermal power of waste packages containing low, medium, and high burnup fuels. Horizontal lines indicate modeled thermal power limits associated with peak waste package temperatures for each repository design concept, and the intersections of the thermal decay curves with the horizontal power limits indicates the aging time required before emplacement for each disposal concept. Waste package surface temperature limits of $100^{\circ} \mathrm{C}, 150^{\circ} \mathrm{C}$, and $200^{\circ} \mathrm{C}$ are hypothesized for disposal concepts that call for clay buffers and backfill. A limit of $200^{\circ} \mathrm{C}$ is used for salt and hard rock concepts without backfill, each shown for two different repository layout options. The lower limit of $100^{\circ} \mathrm{C}$ for disposal concepts with backfill is consistent with limits assumed for existing disposal concepts in France, Sweden, and Finland, and represents a conservative approach to ensuring that properties of the bentonite clay buffer surrounding the waste package in these concepts are not degraded. The higher limit for salt reflects the absence of a bentonite buffer and is safely below the temperature at which crystalline salt decrepitates. The higher limit for hard rock concepts without backfill (of which Yucca Mountain is the only well-documented example) is consistent with design concepts that allow peak temperatures in the wall rock to go above boiling.

Figure 5 should be interpreted with caution because temperature estimates are strongly dependent on the repository layout (i.e., spacing between waste packages within an emplacement drift and spacing between drifts), fuel burnup and waste package loading, and assumptions about the rate and duration of repository ventilation after emplacement and before drifts are sealed. With these caveats noted, however, qualitative observations from Figure 5 are straightforward.

- Higher burnup fuels will require longer cooling times than low burnup fuel (either above ground or with ventilation in the repository) before the repository can be sealed.

- Disposal concepts that require backfill are likely to require unrealistically long aging times for disposal of waste packages containing 32 PWR assemblies, regardless of burnup, primarily because heat retention due to the relatively low thermal conductivity of the backfill.

- Disposal of older low burnup fuel in large waste packages may be feasible with little or no additional aging in either salt (primarily because of its relatively high thermal conductivity) or hard rock designs that do not call for backfill.

- Large waste packages containing high burnup fuel are likely to require many decades of aging before disposal in any concept.

- Aging times can be significantly reduced by increasing spacing between waste packages in the repository.

Disposal of some already-loaded DPCs without repackaging the spent nuclear fuel may also pose complications for licensing analyses of postclosure criticality control because neutron absorber materials used in existing designs are aluminum-based and will degrade with long-term exposure to groundwater. In all cases, the potential for criticality is negligible as long waste packages remain intact and water does not reach the fuel assemblies. If packages fail following disposal and fill with water, the potential for criticality rises and can become a concern once neutron absorber plates degrade. Options 
for assuring postclosure criticality control without opening existing DPCs include robust overpacks that limit the potential for waste package failure, analysis of uncredited reactivity margin associated with the specific loading details of each DPC, and partial reliance on neutron sorption by chloride in saline groundwaters. For those alreadyloaded DPCs for which postclosure criticality remains a concern, opening canisters to insert neutron-absorbing filler materials may be an option [30].

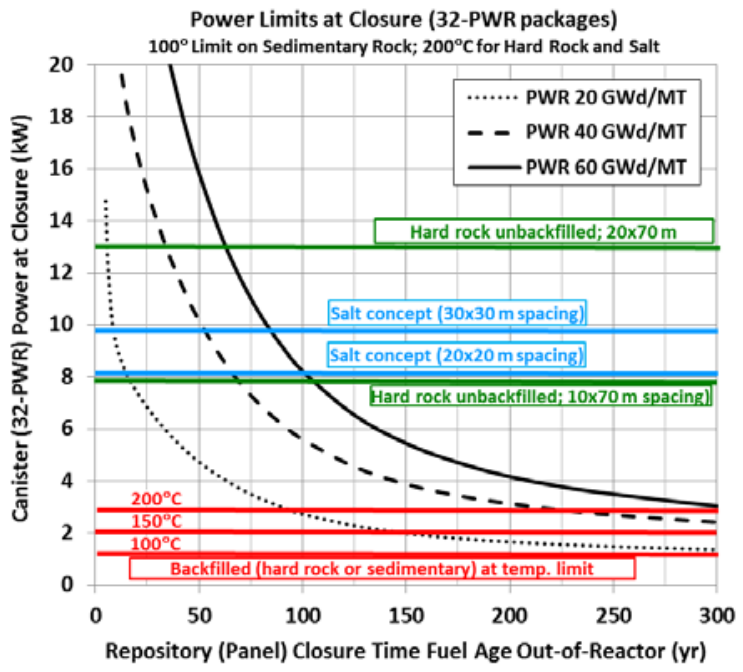

Figure 5. Cooling time needed before repository closure to meet waste package surface temperature constraints for a hypothetical waste package containing 32 PWR assemblies, shown for low, medium and high burnup fuel in various repository design concepts. (Reproduced from [30], Figure 2-29).

\section{OPTIONS FOR AN INTEGRATED SYSTEM}

An optimal solution for integrated management of spent nuclear fuel would maximize the operational efficiency of nuclear power plants, minimize handling of spent fuel and associated occupational radiation doses at all steps in the process, provide for efficient transportation of spent fuel as it moves from reactors to repositories, and support a broad range of permanent geologic disposal options. Costs should be evaluated at the full system level, and should be minimized while meeting all other constraints. Safety and security should not be viewed as adjustable metrics in the debate: they are boundary conditions that must be met regardless of cost. All solutions for spent nuclear fuel management and disposal, including the suboptimal system in place today, must be safe and secure.

One straightforward approach the DOE has investigated would be to introduce a standardized transportation, aging, and disposal (STAD) canister that could be loaded directly from reactor pools and either stored on site or shipped to a consolidated interim storage site while awaiting permanent disposal [32-37]. This approach would do nothing 
to resolve issues associated with existing DPCs, but could provide more efficient management of future spent nuclear fuel discharges and fuel that remains in pool storage. Challenges facing implementation of a STAD concept include 1) the lack of a repository design that would help define the characteristics of the STAD, 2) the lack of financial incentives for utilities to use a STAD, and 3) the passage of time. There is no realistic prospect for implementing STADs in the US before roughly 2030 at the earliest, by which time more than 50,000 MTHM of spent fuel will be in dry storage (Figure 3).

Approaches for managing spent fuel that is already in dry storage and that will be loaded into DPCs in the future focus on two alternatives: options for shipping DPCs to consolidated interim storage facilities where fuel can be repackaged later into repository-specific disposal packages [38,39], and options for direct geologic disposal of sealed DPCs without repackaging [30].

\section{CONCLUSIONS}

There is widespread agreement that there are potentially significant benefits from integrating spent nuclear fuel management practices across all phases of the back end of the nuclear fuel cycle $[4,40,41]$. Efforts to achieve that integration in the US have been unsuccessful to date. Specifically, current practice in the US for dry storage of spent fuel in DPCs at existing reactor sites represents an unstated commitment to the future implementation of some combination of three options:

- Repackaging spent nuclear fuel in the future before disposal

- Constructing one or more repositories that can accommodate DPCs

- Storing spent fuel at surface facilities indefinitely, repackaging as needed.

Each of these options is technically feasible, but none is what was originally planned, and each comes with significant drawbacks. Repackaging spent nuclear fuel that has already been loaded into DPCs will be expensive and will unavoidably result in additional occupational radiation dose to workers that would be avoided if the canisters could be sent directly to disposal. Constructing one or more repositories that can accommodate DPCs is technically feasible, but it will surely complicate the task of siting and licensing a disposal facility, and could add additional delay to a process that is already decades behind schedule. Storing spent fuel at surface facilities indefinitely can be done safely given a commitment to indefinite security and maintenance with repackaging as needed [18], but it commits future generations to the financial costs of spent fuel management and fails to achieve the long-recognized goal of permanent geologic disposal.

The US is unlikely to achieve a single unified and optimal solution to the problems of spent nuclear fuel management. Rather, the future is likely to include some combination of the various options discussed in this paper. Eventually, the US will identify a repository location and design, and it will be possible to load spent nuclear fuel remaining in pools at that time directly into standardized canisters suitable for disposal. Some of the spent nuclear fuel already loaded into DPCs will probably need to be repackaged for disposal, and some DPCs may be found to be suitable for disposal without repackaging.

Given this complexity, a pragmatic approach might begin by looking for incremental actions that could be taken in the near future to provide the greatest flexibility in the coming decades. Efforts could focus on identifying barriers to implementing integrated spent nuclear fuel management practices that can be addressed within existing policy constraints. Even small actions now have can have large impacts 
over the decades during which the current reactor fleet will continue to operate, and potential benefits to the US could be significant.

\section{ACKNOWLEDGMENTS}

The authors thank Josh Peterson and Robby Joseph of Oak Ridge National Laboratory for help in preparing Figure 1, and Geoff Freeze and Ernest Hardin for helpful reviews of preliminary drafts of the paper. Sandia National Laboratories is a multimission laboratory managed and operated by National Technology and Engineering Solutions of Sandia LLC, a wholly owned subsidiary of Honeywell International Inc. for the U.S. Department of Energy's National Nuclear Security Administration under contract DE-NA0003525. This paper is Sandia publication SAND2017-13610J. The United States Government retains and the publisher, by accepting the article for publication, acknowledges that the United States Government retains a non-exclusive, paid-up, irrevocable, world-wide license to publish or reproduce the published form of this manuscript, or allow others to do so, for United States Government purposes. The statements expressed in this article are those of the authors and do not necessarily reflect the views or policies of the United States Department of Energy or Sandia National Laboratories.

\section{REFERENCES}

1. National Research Council / National Academy of Sciences, The Disposal of Radioactive Waste on Land, Report of the Committee on Waste Disposal of the Division of Earth Sciences (National Academy of Sciences - National Research Council Publication 519, Washington DC, 1957).

2. National Research Council / National Academies, Disposition of High-Level Waste and Spent Nuclear Fuel: The Continuing Societal and Technical Challenges (National Academy Press, Washington DC, 2001) $198 \mathrm{p}$.

3. United States Nuclear Waste Technical Review Board, Experience Gained from Programs to Manage High-Level Radioactive Waste and Spent Nuclear Fuel in the United States and Other Countries, A Report to Congress and the Secretary of Energy, (Arlington VA, USA, 2011) $70 \mathrm{p}$.

4. Blue Ribbon Commission on America's Nuclear Future, Report to the Secretary of Energy (2012) $157 \mathrm{p}$.

5. United States Department of Energy, Final Environmental Impact Statement for Decommissioning and/or Long-Term Stewardship at the West Valley Demonstration Project and Western New York Nuclear Service Center, Executive Summary (DOE/EIS0226, 2010) $63 \mathrm{p}$.

6. J.S. Walker, The Road to Yucca Mountain, (University of California Press, 2009), p. 106110 .

7. R. Reagan, Statement Announcing a Series of Policy Initiatives on Nuclear Energy (October 8, 1981) Available online by Gerhard Peters and John T. Woolley, The American Presidency Project. http://www.presidency.ucsb.edu/ws/?pid=44353 (accessed 5 December 2017).

8. The Nuclear Waste Policy Act of 1982, as amended, 42 U.S.C. 10101 and following.

9. United States Department of Energy, Yucca Mountain Repository License Application. (DOE/RW-0573, Update no. 1, 2008) 8344 p. 
10. United States Department of Energy, Strategy for the Management and Disposal of Used Nuclear Fuel and High-Level Radioactive Waste (2013), 32 p.

11. United States Department of Energy Office of Civilian Radioactive Waste Management, January 2009 Project Decision Schedule (DOE/RW-0604, 2009) 17p.

12. Curie Map (Oak Ridge National Laboratory, 2017), Available at: https://curie.ornl.gov/map (accessed December 5, 2017).

13. United States Nuclear Regulatory Commission, Spent Fuel Pools, available at https://www.nrc.gov/waste/spent-fuel-storage/pools.html (accessed December 5, 2017).

14. United States Nuclear Regulatory Commission, Dry Cask Storage, available at https://www.nrc.gov/waste/spent-fuel-storage/dry-cask-storage.html (accessed December 5, 2017).

15. R. H. Jones, Dry Storage Cask Inventory Assessment (U.S. Department of Energy FCRDNFST-2014-000602, Revision 2, 2016) 170 p.

16. J.C. Wagner, J.L. Peterson, D.E. Mueller, J.C. Gehin, A. Worrall, T. Taiwo, M. Nutt, M.A. Williamson, M. Todosow, R. Wigeland, W.G. Halsey, R.P. Omberg, P.N. Swift, and J.T. Carter, Categorization of Used Nuclear Fuel Inventory in Support of a Comprehensive National Nuclear Fuel Cycle Strategy (Oak Ridge National Laboratory ORNL/TM2012/308. FCRD-FCT-2012-000232, 2012) 98 p.

17. J. Carter, D. Vinson, and J. Wilson, Commercial Spent Nuclear Fuel and High-Level Radioactive Waste Inventory Report (U.S. DOE Office of Spent Fuel and Waste Management FCRD-NFST-2013-000263 Rev. 4 SRNL-STI-2016-00360, 2016) 176 p.

18. United States Nuclear Regulatory Commission, Generic Environmental Impact Statement for Continued Storage of Spent Nuclear Fuel (NUREG-2157 Volume 1, 2014), 687 p.

19. United States Nuclear Regulatory Commission, A Pilot Probabilistic Risk Assessment Of a Dry Cask Storage System At a Nuclear Power Plant (NUREG-1864, 2007), 299 p.

20. United States Nuclear Regulatory Commission, Managing Aging Processes in Storage (MAPS) Report: Draft Report for Comment (NUREG-2214, 2017), 517 p.

21. B. Hanson, H. Alsaed, C. Stockman, D. Enos, R. Meyer, K. Sorenson, Gap Analysis to Support Extended Storage of Used Nuclear Fuel Rev. 0 (U.S. Department of Energy Office of Used Nuclear Fuel Disposition FCRD-USED-2011-000136 Rev. 0 PNNL-20509, 2012) 218 p.

22. Electric Power Research Institute, High Burnup Dry Storage Cask Research and Development Project Final Test Plan (prepared by Electric Power Research Institute for the U.S. Department of Energy under contract DE-NE-0000593, 2014) 60 p.

23. S. Saltzstein, K. Sorenson, B. Hanson, and P. Swift, US DOE Spent Nuclear Fuel Storage and Transportation R\&D Activities (proc. IHLRWM2017, 2017) p. 90-97.

24. S.J. Maheras, R.E. Best, S.B. Ross, K.A. Buxton, J.L. England, P.E. McConnell, L.M. Massaro, P.J. Jensen, Preliminary Evaluation of Removing Used Nuclear Fuel from Shutdown Sites (U.S. Department of Energy Nuclear Fuels Storage and Transportation Planning Project SFWD-IWM-2017-000024, PNNL-22676 Rev. 10, 2017) 452 p.

25. AREVA Federal Services LLC, Design and Prototype Fabrication of Railcars for Transport of High-Level Radioactive Material. Phase 1: Mobilization and Conceptual Design (prepared by AREVA Federal Services LLC for the U.S. Department of Energy under contract DE-NE-0008390, 2016) 373 p.

26. Stockman, C. and E. Kalinina, Cooling Times for Storage and Transportation of Spent Nuclear Fuel (Sandia National Laboratories, Albuquerque NM, SAND NO. 2013-2013P, 2013) $10 \mathrm{p}$.

27. SKB (Svensk Kämbränslehantering AB), Long-Term Safety for the Final Repository for Spent Nuclear Fuel at Forsmark: Main Report of the SR-Site Project Volume 1 (Technical Report TR-11-01, 2011), $270 \mathrm{p}$.

28. Posiva Oy, Safety Case for the Disposal of Spent Nuclear Fuel at Olkiluoto-Synthesis 2012 (POSIVA 2012-12, 2012) 324 p. 
29. ANDRA (Agence nationale pour la gestion des déchets radioactifs), Dossier 2005: Argile. Tome: Safety Evaluation of a Geological Repository (English translation: original documentation written in French remains ultimately the reference documentation, 2005), $784 \mathrm{p}$.

30. E.L. Hardin, L. Price, E. Kalinina, T. Hadgu, A. Ilgen, C Bryan, J. Scaglione, K. Banerjee, J. Clarity, R. Jubin, V. Sobes, R. Howard, J. Carter, T. Severynse, and F. Perry, Summary of Investigations on Technical Feasibility of Direct Disposal of Dual-Purpose Canisters (U.S. Department of Energy Office of Used Nuclear Fuel Disposition FCRD-UFD-2015-000129 Rev 0, 2015) $117 \mathrm{p}$

31. E. Hardin, J. Blink, H. Greenberg M. Sutton, M. Fratoni, J. Carter, M. Dupont, R. Howard, Generic Repository Design Concepts and Thermal Analysis (FY11) (U.S. Department of Energy Office of Used Nuclear Fuel Disposition FCRD-USED-2011-0002143 Rev. 2, 2011) $272 \mathrm{p}$.

32. AREVA Federal Services LLC, Task Order 12-Standardized Transportation, Aging, and Disposal Canister Feasibility Study (prepared for the U.S. Department of Energy under contract no. A\&AS DE-NE-0000291, RPT-3008097-000, 2013) 143 p.

33. Energy Solutions, NAC International, Exelon Nuclear Partners, Booz Allen Hamilton, Talisman International LLC, Terranear PMC, and Sargent and Lundy LLC, Task Order 12: Standardized Transportation, Aging, and Disposal Canister Feasibility Study (prepared for the U.S. Department of Energy Office of Spent Fuel and Waste Management, 2013) 239 p.

34. Energy Solutions, NAC International, Exelon Nuclear Partners, and Booz Allen Hamilton, Task Order 21: Operational Requirements for Standardized Dry Fuel Canister Systems, Updated Final Report (prepared for the U.S. Department of Energy Office of Spent Fuel and Waste Management, 2015) 224 p.

35. Energy Solutions, NAC International, Exelon Nuclear Partners, Booz Allen Hamilton, Talisman International LLC, Petersen Incorporated, Task Order 18: Generic Design for Small Standardized Transportation, Aging, and Disposal Canister Systems, Updated Final Report (prepared for the U.S. Department of Energy Office of Spent Fuel and Waste Management, 2015) $317 \mathrm{p}$.

36. J. Jarrell, R. Joseph, R. Howard, R. Hale, G. Petersen, B. Wilkerson, J. Fortner, E. Kalinina, Initial Standardized Canister System Evaluation (U.S. Department of Energy Nuclear Fuels Storage and Transportation Planning Project FCRD-NFST-2014-000084, Rev. 1, ORNL/LTR-2014-330, 2015), 112 p.

37. Oak Ridge National Laboratory, Performance Specification for Standardized Transportation, Aging, and Disposal Canister Systems (U.S. Department of Energy Nuclear Fuels Storage and Transportation Planning Project FCRD-NFST-2014-000579, Rev. 2, ORNL/SPR-2015/251, 2015) 40 p.

38. R. M. Cumberland, K.A. Williams, J.J. Jarrell, R. A. Joseph III, Cost Sensitivity Analysis for Consolidated Interim Storage of Spent Fuel: Evaluating the Effect of Economic Environment Parameters, (U.S. Department of Energy Office of Spent Fuel and Waste Management FCRD-NFST-2016-000721, Rev. 1, ORNL/SR-2016/681 2016) 26 p.

39. J. Jarrell, J., R. Joseph, R. Howard, G. Petersen, R. Cumberland, M. Nutt, J. Carter, and T. Cotton, Cost Implications of an Interim Storage Facility in the Waste Management System (U.S. Department of Energy FCRD-NFST-2015-000648 Rev.1 ONRL/TM-2015/18, 2016) $46 \mathrm{p}$.

40. R.P. Rechard, L.L. Price, and E.A. Kalinina, Integrating Management of Spent Nuclear Fuel from Generation to Disposal (Sandia National Laboratories, Albuquerque, NM USA, SAND2015-5503, 2015), 45 p.

41. International Energy Agency, Potential Interface Issues in Spent Fuel Management, (IAEATECDOC-1774, 2015), $172 \mathrm{p}$. 